Maria Simonsen, post.doc., ph.d. i bok och

biblioteksthistoria fra Lunds Universitet, ansat på

Aalborg Universitet, Institut for Politik og Samfund, og tilknyttet Historiestudiet. Maria Simonsen har skrevet om skandinavisk encyklopædihistorie, forlagshistorie og videnshistorie. Hun arbejder pt. på et projekt om den aldrig udgivne encyklopædi Den Store Salmonsen.

Keywords: Internationale organisationer, videnshistorie, boghistorie, videnscirkulation, tidsskriftshistorie.

\title{
ET VINDUE TIL VERDEN
}

\section{Fra forfatning til tidsskrift - en undersøgelse}

\section{af videnstransformation og -cirkulation}

\section{i UNESCO Courier ${ }^{1}$}

I februar 1948 udgav UNESCO første nummer af tidsskriftet the Courier. Formålet var at skabe en platform, hvorfra organisationen kunne formidle viden om sine mange forskelligartede aktiviteter i arbejdet med at promovere fredelige og demokratiske værdier efter Anden Verdenskrig. Ud fra et videnshistorisk perspektiv er UNESCO en særdeles interessant organisation, på grund af dens omfattende ambitioner i forhold til at producere, formidle og cirkulere viden på flere forskellige niveauer. Hvordan løftes UNESCOs idéer og idealer fra officielle dokumenter, som f.eks. en forfatning eller en resolution, der er henvendt til et politisk niveau, til en udgivelse som the Courier, der er rettet mod et ikkespecialiseret publikum internationalt. Hvad sker der med UNESCOs idéer og idealer, når de er i bevægelse? Hvordan udtrykkes eller oversættes den viden, som UNESCO formidler i sine officielle dokumenter i nye former og medier, når modtageren forandres?

1 Forfatteren vil gerne takke Poul Duedahl for muligheden for at deltage i forskningsprojektet 'The Global History of UNESCO'. Tak også til medredaktørerne bag temanummeret, Lars Andersen, Ivan Lind Christensen og Louise Skyggebjerg for nyttige kommentarer, samt til Signe Mellemgaard og Martin Vestergaard Jensen for gode råd undervejs i artikelarbejdet. 
„To Our Readers,

With this first issue we begin the publication of UNESCO Courier, a periodical designed to inform the public of the activities of the Specialised Agency of the United Nations for Education, Science and Culture."2

I februar 1948 udgav UNESCO, FN's organisation for uddannelse, videnskab og kultur, det første nummer af tidsskriftet UNESCO Courier. ${ }^{3}$ Formålet med udgivelsen var at skabe en platform, hvorfra organisationen kunne formidle viden om sine mange forskelligartede aktiviteter i arbejdet med at promovere fredelige og demokratiske værdier efter Anden Verdenskrig. Evnen til at formidle dens mission til mennesker udenfor hovedkvarteret i Paris, var fra begyndelsen en central del i UNESCOs arbejde. Hensigten var at komme ud til en bredere offentlighed som f.eks. skolelærere, studerende, eller lokalt engagerede via skolebøger, tidsskrifter, film eller radioprogrammer og derigennem nå udover de traditionelle politiske cirkler.

Som historiker Poul Duedahl tidligere har beskrevet, blev UNESCO ,sat i verden for at gennemføre et stykke mental ingeniørkunst, der skulle ændre tankegangen hos mennesker overalt på kloden“. ${ }^{4}$ I det arbejde spillede de mere folkelige udgivelser en helt central rolle og udgivelsen af the Courier var et af flere led i UNESCOs tidlige kommunikationsstrategi. Men tidsskriftet fik status af andet og mere end blot formidler. Ifølge Irina Bokova, generaldirektør for UNESCO i perioden 2009-17, har the Courier, i løbet af de sidste 70 år, etableret sig som ,a key element of UNESCO's identity as well as one of the most powerful tools for its humanistic mandate". ${ }^{5}$ Tidsskriftets lange levetid betyder, at the Courier indeholder et rigt materiale som ikke kun viser, hvordan UNESCO har formidlet sine aktiviteter, men også hvordan organisationens idéer, idealer og værdier er kommet til udtryk i praksis og har udviklet sig gennem årene.

I kølvandet på de to verdenskrige opstod et stort antal mellemstatslige såvel som ikke-statslige organisationer (NGO'er), der alle havde det til fælles, at de blev vigtige producenter og distributører af viden, som var tiltænkt at sætte dagsordenen for verdenssamfundet som helhed. Den viden som udgik fra de forskellige organisationer, blandt andet i form af forfatninger, resolutioner, anbefalinger eller rapporter, havde til hensigt at sætte standarder for og vejlede verdens lande i, hvordan de skulle opføre sig og agere f.eks. i relation til menneskerettigheder og i militære og økonomiske forhold. UNESCO var blandt efterkrigstidens mest

\footnotetext{
UNESCO Courier, februar 1948, s. 1.

De fuldstændige titler på de to tidsskrifter som indgår i artiklens undersøgelser, er UNESCO Monitor og UNESCO Courier. I artiklen henviser jeg dog til tidsskrifterne som the Courier og the Monitor.

4 Duedahl 2015, s. 34.

5 UNESCO Courier, april-juni 2017, s. 5.
} 
indflydelsesrige vidensproducerende organisationer. Ikke mindst fordi organisationen, modsat f.eks. OECD eller NATO, som begge henvendte sig til og opererede på et politisk niveau, havde opmærksomheden rettet mod en langt større skare.

Set ud fra et videnshistorisk perspektiv er UNESCO en særdeles interessant organisation på grund af dens omfattende ambitioner i forhold til at producere, formidle og cirkulere viden på flere forskellige niveauer. ${ }^{6}$ I artiklen vil jeg derfor undersøge UNESCO som en international videnscirkulerende organisation. Med afsæt i udgivelserne the Courier og dens kortlivede forgænger the Monitor vil jeg give indsigt i en del af den videnstransformation og -cirkulation, der blev iværksat af UNESCO inden for uddannelsesområdet. ${ }^{7}$ Formålet er at give eksempler på, hvordan UNESCOs idéer og idealer i organisationens tre første årtier løftes fra officielle dokumenter, som f.eks. en forfatning eller en resolution, der er henvendt til et politisk niveau, til udgivelser rettet mod et ikke-specialiseret publikum internationalt. Hvad sker der med UNESCOs idéer og idealer, når de er i bevægelse? Hvordan udtrykkes eller oversættes den viden som UNESCO formidler i sine officielle dokumenter i nye former og medier, når modtageren forandres? Det er de spørgsmål, som undersøgelsen vil give et svar på.

Til trods for tidsskriftets nøglerolle i UNESCOs kommunikative arbejde, er the Couriers udgivelseshistorie alene blevet fortalt i mindre artikler med et stærkt personalhistorisk fokus, mens dens samlede udgivelseshistorie er trådt i baggrunden. Derfor vil jeg undervejs også give indblik i baggrunden for etableringen af the Courier og dens forgænger the Monitor. I undersøgelsen af videnstransformation og -cirkulation fra de politiske styredokumenter til de to UNESCO-tidsskrifter, vil jeg kombinere perspektiver fra henholdsvis bog- og videnshistorien, herunder de schweiziske historikere Philip Sarasins og Andreas Kilchers trestrengede forståelse af cirkulationsbegrebet samt det boghistoriske kommunikationskredsløb. ${ }^{8}$ Ved at kombinere perspektiver fra de bog- og videnshistoriske felter, er det muligt at vise nye sider af UNESCOs arbejde; nemlig hvordan værdier og idealer som udtrykkes i henholdsvis forfatningen og resolutioner på uddannelsesområdet, kommer til udtryk og/eller transformeres i udgivelser, der er rettet mod et bredere publikum - i tilfældet her læsere af the Monitor og the Courier. I undersøgelsen vil der være særlig fokus på tidsskrifternes materialitet, herunder deres typografiske udtryk, og sammenhængen med deres vidensformidling og -tilgængelighed.

6 UNESCO: Constitution of the United Nations Educational, Scientific, and Cultural Organization. Adopted in London on 16 November 1945.

7 Kildematerialet, som undersøgelsen bygger på, er som det fremgår af artiklen de to udgivelser the Monitor og the Courier. I arbejdet med artiklen har jeg gennemgået the Monitor og the Courier i perioden 1946-1975, som begge findes digitaliserede i UNESCOs online arkiv - UNESCO Archives database Access to Memory (AtoM) og i UNESDOC, Digital Library.

8 I afsnittet „Videnscirkulation“ forklarer jeg de to 'cirkulationsmetoder', samt hvordan de kommer til anvendelse i undersøgelsen af the Monitor og the Courier. Se også Darnton 1982; Darnton 2007; Sarasin \& Kilcher 2011; Östling \& Heidenblad 2017. 
Undersøgelsen koncentreres om de tre første årtier af UNESCOs virke, fra 1947 til 1975. Som det fremgår senere i artiklen, udkommer tidsskrifterne ikke kontinuerligt eller parallelt igennem hele perioden, men afløser hinanden; the Monitor publiceredes i tre udgaver fra august til november i 1947, mens the Courier begyndte at udkomme fra februar 1948. Uddannelsesområdet er en omfattende størrelse på alle niveauer af UNESCOs arbejde. I artiklen koncentrerer jeg derfor undersøgelsen til at omfatte pigers og kvinders muligheder på uddannelsesområdet fra udgivelsen af the Monitors første nummer og til FN’s kvindeår i 1975.

\section{„Since wars begin in the minds of men...“}

UNESCO er et resultat af det verdenssamarbejde, der blev iværksat som en reaktion på de to verdenskrige. Først med etableringen af Folkeforbundet i 1919, der, som en del af Versailles-Traktaten, afsluttede Første Verdenskrig og hvis indsatser efterfølgende blev afløst af og overflyttet til FN i april 1946, syv måneder efter Anden Verdenskrigs afslutning. ${ }^{9}$ Det er i lyset af de to verdenskrige, at vi skal forstå UNESCOs mission om at ville udbrede og cirkulere viden, der havde til hensigt at etablere en ny verdensorden, hvor fred og demokrati stod øverst på dagsordenen.

UNESCOs arbejde tager udgangspunkt i de fire kernepunkter; uddannelse, videnskab, kultur og kommunikation. Uddannelsesaspektet er imidlertid det altoverskyggende fokus - også selvom det i akronymet sidestilles med kultur og videnskab. ${ }^{10} \mathrm{Ud}$ fra UNESCOs optik åbner uddannelse op for adgang til samfundet som helhed og gennem uddannelse får det enkelte menneske mulighed for at læse og forstå, hvilke rettigheder, muligheder, begrænsninger og forpligtelser man som gruppe og individ har i samfundet. I UNESCOs øjne er uddannelse dermed en grundlæggende menneskerettighed - et redskab til at forstå og gøre brug af alle øvrige rettigheder, der ellers ville forblive illusoriske og teoretiske størrelser for størstedelen af verdens befolkning. ${ }^{11}$

I præamblen til UNESCOs forfatning, der blev vedtaget i London i november 1945, blev det understreget, at det fredsskabende arbejde fremfor alt begynder ved at påvirke menneskers måde at tænke på: „Since wars begin in the minds of men, it is in the minds of men that defences of peace must be constructed". ${ }^{12}$ At uddannelse var et centralt redskab i arbejdet med at nå netop det mål, blev pointeret gentagne gange i forfatningsteksten, ${ }^{13}$ og i organisationens første år var der

9 Duedahl 2016, s. 3; se også Valderrama 1995.

10 Droit 2005, s. 57.

11 Simonsen 2007.

12 UNESCO: Constitution of the United Nations Educational, Scientific, and Cultural Organization. Adopted in London on 16 November 1945, Præamblen; Duedahl, 2016, s. 3.

13 UNESCO: Constitution of the United Nations Educational, Scientific, and Cultural Organization. Adopted in London on 16 November 1945, Artikel 1, 'Purposes and Functions'. 
et stærkt fokus på forskellige aspekter af uddannelse, blandt andet gennem omfattende initiativer, såsom et program for fundamental uddannelse for alle, ${ }^{14}$ voksenundervisning, samt revidering af skolebøger, der blev iværksat internationalt såvel som nationalt via nationalkommissioner og/eller i samarbejde med lokale NGO’er. ${ }^{15}$ I dag står uddannelsesaspektet fortsat højt på UNESCOs dagsorden, der blandt andet markeres gennem flere internationale mærkedage som International Day of Education (24. januar), World Book and Copyright Day (24. april), International Literacy Day (8. september) og World Teachers' Day (5. oktober).

Initiativer i forhold til kommunikation generelt og massekommunikation i særdeleshed spillede en væsentlig rolle i UNESCOs arbejde på uddannelsesområdet. Selvom kommunikation ikke er nævnt i akronymet, har det, sammen med uddannelse, haft en nøgleposition i organisationens aktiviteter, ${ }^{16}$ og i forfatningen blev UNESCOs rolle og ansvar i forhold til at opretholde og øge udbredelsen af viden flere gange påpeget. Eksempelvis forpligtede medlemsstaterne sig til at arbejde for at „,collaborate in the work of advancing the mutual knowledge and understanding of peoples, through all means of mass communication and to that end recommend such international agreements as may be necessary to promote the free flow of ideas by word and image“. ${ }^{17}$ Ved brug af massekommunikation ville UNESCO skabe en fri strøm og „udveksling af idéer og viden over alt i hele verden “. ${ }^{18}$ Fra første færd udtrykte UNESCO således bevidsthed om sin position som både vidensproducent og -formidler, samt vigtigheden af at arbejde via flere forskellige kanaler, i forhold til at forfølge det demokrati- og fredsskabende arbejde.

At udtrykke hensigter i et officielt dokument er kun et første skridt. At nå ud til og påvirke verdens befolkning kræver andre måder at formidle på. En særlig opgave i forbindelse med at kommunikere til et større publikum bestod i at producere og cirkulere videnskabelig litteratur, skolebøger og andet trykt materiale, der var med til at promovere organisationens værdisæt. Gennem årene har UNESCO finansieret og udgivet en lang række værker, som byggede på større forskningsprojekter, f.eks. General History of Africa og History of Civilizations of Central Asia, men også meget udbredte håndbøger som UNESCO Source Book for Science Teaching og periodika som the Courier. Samtidig medvirkede de enkelte medlemslandes nationale kommissioner, iblandt i samarbejde med lokale NGO'er, til at udgive UNESCO-sponsorerede publikationer på nationalsprog, herunder skolebøger, tematiske pjecer eller egne tidsskrifter. På den måde har UNE-

\footnotetext{
14 Boel 2017, s. 153-167.

15 Duedahl 2016.

16 Defourny 2003.

17 UNESCO: Constitution of the United Nations Educational, Scientific, and Cultural Organization. Adopted in London on 16 November 1945, Artikel 1(a), 'Purposes and Functions'. 
SCO udbredt sit værdisæt gennem en bred vifte af forskellige trykte medier, og de mange publikationer viser, hvordan massekommunikation fra begyndelsen havde en central position i FN-organisationens forskellige initiativer og aktiviteter. ${ }^{19}$

\section{Videnscirkulation}

Spørgsmålet om, hvordan viden cirkulerer blandt aktører og på tværs af nationale, kulturelle, institutionelle, disciplinære, politiske og sociale grænser, siger historiker Simone Lässig, „stands at the center of a history of knowledge that sees „knowledge“ as a promising avenue to better understanding societies“. ${ }^{20}$ En undersøgelse af videnstransformation og -cirkulation i en international institution som UNESCO, kan på samme måde give indblik i, hvordan organisationen rent praktisk har formidlet og sat viden om dens idéer og idealer i cirkulation. Derigennem kan vi også få indsigt i, hvilken rolle de trykte medier har haft i formidlingsarbejdet, samt hvordan vidensformidlingen har forandret sig over tid.

Begrebet videnscirkulation har vundet indpas internationalt såvel som blandt skandinaviske historikere med opkomsten af det videnshistoriske forskningsfelt. ${ }^{21}$ Som idéhistoriker Suzanne Marchand har peget på, er fortalerne for videnshistorie ,,in general agreement about the external factors which have contributed to its evolution: the advent of big science and the digital revolution, to begin with, have posed new questions about how knowledge in the past has been generated and communicated“. ${ }^{22}$ Videnscirkulation kan undersøges ved at stille spørgsmål til, hvordan og hvorfor viden cirkulerer, og/eller hvordan viden er blevet formet eller omformet, når det flytter fra ét medie til et andet og/eller skifter målgruppe. Cirkulationsbegrebet er, som historikerne Johan Östling og David Larsson Heidenblad har påpeget, ikke en ny opfindelse i historievidenskaberne, og det er udbredt inden for flere historiefaglige grene såsom global-, populær-, og uddannelseshistorie for blot at nævne nogle enkelte eksempler. ${ }^{23}$

Diskussionen om og studiet af videnscirkulation udviklede sig for alvor med James Secords artikel „Knowledge in Transit“ (2004), hvor han foreslår følgende forskningsspørgsmål i arbejdet med videnscirkulation: „How and why does knowledge circulate? How does it cease to be the exclusive property of a single individual or group and become part of the taken-for-granted understanding of

19 UNESCOs initiativer i forhold til massekommunikation omfattede også andre medier end de trykte, herunder radio og film. Artiklen her fokuserer dog alene på tidsskrifter. For anden forskning i UNESCOs brug af trykte medier i sine værdipolitiske indsatser se f.eks. den franske historiker Céline Giton. Giton 2019.

20 Lässig 2016, s. 43.

21 Östling \& Heidenblad 2017, s. 269-284; Östling et al. 2018, Introduction.

22 Marchand 2019, s. 130.

23 Östling \& Heidenblad 2017, s. 269-284. 
much wider groups of people?““. ${ }^{24}$ Især det sidste spørgsmål er interessant at stille til UNESCO qua organisationens rolle som vidensproducerende og -cirkulerende aktør. Hensigtserklæringer og anbefalinger i organisationens officielle dokumenter var tænkt at skulle formidles fra hovedkvarteret i Paris til verdens offentlighed, og derigennem lede til konkrete handlinger og forandringer, som kunne bidrage til gennemførelsen af UNESCOs forskellige målsætninger.

Siden udgivelsen af „Knowledge in Transit“ er cirkulationsbegrebet blevet diskuteret, udviklet og kritiseret af en lang række forskere, der arbejder indenfor såvel som udenfor det videnshistoriske felt. ${ }^{25}$ Det er imidlertid ikke denne artikels ærinde at fremlægge den omfattende debat. ${ }^{26}$ I stedet vil jeg fokusere på den forståelse af cirkulationsbegrebet, der er blevet løftet frem i det schweiziske videnshistoriske miljø af Philip Sarasin og Andreas Kilcher, og som har vundet indpas i den skandinaviske forskning om videnscirkulation. Det schweiziske cirkulationsbegreb har flere ligheder med det, som eksisterer inden for det boghistoriske forskningsfelt. Sammen med det videnshistoriske greb udgør disse positioner det metodiske grundlag for nærværende undersøgelse.

I forordet til temanummeret om cirkulation i tidsskriftet Nach Feierabend. Zürcher Jahrbuch für Wissensgeschichte (2011) peger Sarasin og Kilcher på tre faktorer, som karakteriserer anvendelsen af videnscirkulation. ${ }^{27}$ Først og fremmest indebærer cirkulationsbegrebet, at materialitet og medialitet tages alvorligt som bærer af viden, ${ }^{28}$ Sarasin og Kilcher argumenterer således for, at viden ikke bevæger sig frit, men altid er indlejret i sociale sammenhænge, ligesom den hviler på et materielt grundlag. ${ }^{29}$ For det andet sætter de to forskere spørgsmålstegn ved den traditionelle historiske forståelse af videns originalitet og oprindelse. Som Östling og Heidenblad præcist har beskrevet, stiller det videnshistoriske cirkulationsbegrebet spørgsmål ved ,själva principen om spridning och att det skulle finnas något slags startpunkt för kunskapen“. ${ }^{30}$ Viden kan således ikke spores tilbage til sin oprindelse i form af en institutionel eller intellektuel afgrænset kilde. Viden opstår derimod altid i en kulturel produktion og underlagt sociale magtforhold. ${ }^{31}$ Sidst, men ikke mindst, fremhæver Sarasin og Kilcher, at viden ikke er overalt og at den heller ikke er tilgængelig for alle, samt at i enhver analyse af videnscirkulation, må politiske dimensioner ligeledes medtages. Des-

24 Secord 2004, s. 655.

25 Se Östling \& Heidenblad 2017; Lässig 2016; Sarasin \& Kilcher 2011.

26 For en grundig gennemgang cirkulationsbegrebets udvikling internationalt og den sideløbende diskussion, se også Östling \& Heidenblad 2007.

27 Sarasin \& Kilcher 2011.

28 Ibid., s. 9.

29 Sarasin \& Kilcher 2011, s. 9-10; Östling \& Heidenblad 2017, s. 277; Se også Östling et al., 2018, s. 9-33.

30 Östling \& Heidenblad 2017, s. 277.

31 Sarasin \& Kilcher 2011, s. 10. 
uden må det overvejes, hvilke forhindringer, omveje eller blokeringer, der findes i forhold til viden og dens bevægelighed. ${ }^{32}$

\section{Kommunikationskredsløbet vs. cirkulationsbegrebet}

En af de historiediscipliner, hvor cirkulation længe har været et centralt metodisk greb, er boghistorien. I sin skildring af det moderne boghistoriske forskningsfelt, har litteraturhistoriker Jens Bjerring-Hansen forklaret, at der her er en „interesse for tekstens fysiske egenskaber og vilkårene for dens produktion, distribution og konsumption“. ${ }^{33}$ Sidstnævnte er en henvisning til kulturhistoriker Robert Darntons model over kommunikationskredsløbet (the communication circuit), der illustrerer bogens livcyklus fra forfatter til læser, samt interaktionerne mellem de forskellige aktører og de socioøkonomiske og kulturelle vilkår i tiden. ${ }^{34}$

En vigtig, men ofte overset pointe i Darntons model er, at i kommunikationskredsløbet indgår ligeledes omformningen af de budskaber, som bøgerne (eller andre trykte dokumenter som f.eks. tidsskrifter) bærer; „it transmits messages, transforming them en route, as they pass from thought to writing to printed characters and back to thought again“. ${ }^{35}$ Et grundlæggende synspunkt i den moderne boghistoriske forskning er, ,at teksters materielle form og mediet i bred forstand er medskabere af mening, at man med andre ord ikke kan adskille bogen som fysisk genstand fra bogen som kommunikationskanal og bærer af litterært eller æstetisk indhold“. ${ }^{36}$ Der er altså flere paralleller mellem det cirkulationsbegreb som Sarasin og Kilcher præsenterer og det boghistoriske kommunikationskredsløb, ikke mindst i forhold til den materialitet som bærer viden, samt den videnstransformation og -cirkulation som sker, når viden er i proces.

Det er vigtigt at være opmærksom på sammenfaldet mellem de to metodiske tilgange. Desuden kan det være vanskeligt at adskille den boghistoriske metode fra den videnshistoriske, når det gælder brugen af kommunikationskredsløbet og cirkulationsbegrebet. En væsentlig forskel på kommunikationskredsløbet og cirkulationsbegrebet er f.eks., at der i det boghistoriske kredsløb kan siges at være et startpunkt ved det led, som Darnton kalder 'forfatter'. ${ }^{37}$ Lighederne til trods, kan de to metodiske indgange også berige hinanden igennem deres forskellige hovedfokus. Hvor kommunikationskredsløbets styrke er en opmærksomhed på det materielle og på en række aktører og deres interaktion med forskellige socio-

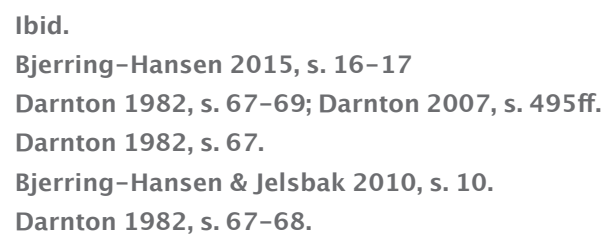


kulturelle faktorer, muliggør „,videnshistoriens cirkulationsbegreb en mere detaljeret undersøgelse af forandringer af selve vidensindholdet, når det cirkulerer i forskellige medier og genrer eller kommer til udtryk i nye former - måske især i forhold til sidstnævnte“. ${ }^{38}$ I fællesskab kan de to metodiske tilgange tydeliggøre, hvordan the Monitor og the Courier er en central del af UNESCOs kommunikationskredsløb.

\section{Etableringen af de første UNESCO-tidsskrifter}

The Courier var blot én blandt en lang række UNESCO-udgivelser, som var tiltænkt et bredere publikum. Det som imidlertid adskiller tidsskriftet fra de øvrige publikationer, er dets lange udgivelsesperiode på mere end 70 år, samt the Couriers store udbredelse i alle dele af verden på tværs af politiske og religiøse skel. Fra sin begyndelse havde UNESCO forstået, at det var nødvendigt at holde offentligheden informeret om organisationens fremgang og udvikling, ${ }^{39}$ og ved den 1. generalkonference i Paris i 1946 lød en af hensigtserklæringerne for Sektionen for Massekommunikation, at den skulle arbejde for at ,publicize the program of UNESCO as much as possible and to initiate a program of mass education, in the broadest sense“. ${ }^{40}$ I august 1947 lancerede organisationen derfor the Monitor, et fire sider langt avislignende tidsskrift i sort-hvid, der havde til formål at informere offentligheden om organisationens aktiviteter. ${ }^{41}$

The Monitor var opbygget omkring et ganske enkelt layout, der bestod af en række faste paratekster. På forsiden gav en kalender information om møder og aktiviteter internt i UNESCO, samt om øvrige aktiviteter, hvor organisationen var repræsenteret, f.eks. på internationale konferencer. På kalenderens venstre side gav redaktionen under overskriften „Paris Newsletter“, en slags tilstandsrapport over, hvad der foregik i organisationen, mens den højre side af kalenderen var reserveret til det mere juridiske stof, herunder aftaler mellem FN og UNESCO eller udgivelsen af officielle rapporter. ${ }^{42}$ Udover de faste elementer var der også enkelte essays, rapporter og artikler, der på forskellig vis gav udtryk for og/eller diskuterede de idéer og idealer, som var blevet præsenteret i forfatningsteksten.

Et eksempel var et to sider langt essay i the Monitors første nummer, hvor Byron Dexter (1900-73), redaktør på det amerikanske tidsskrift Foreign Affairs, kommenterede UNESCOs mål og de metoder, som blev anvendt for at nå dem. ${ }^{43} \mathrm{I}$

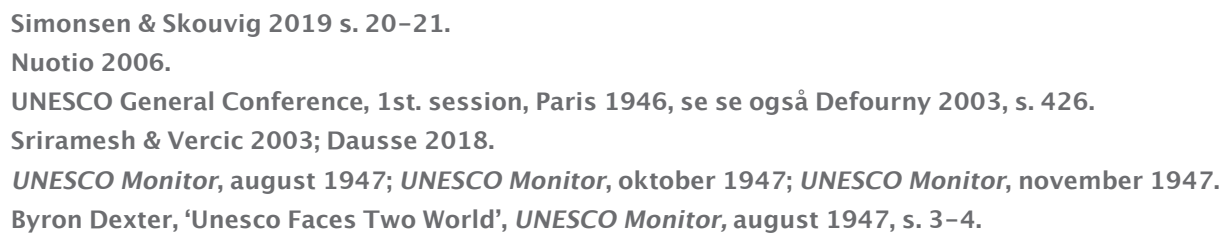




\section{Fis. \\ INESCO

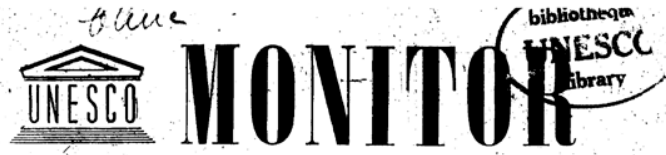

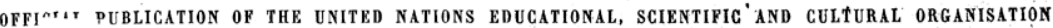

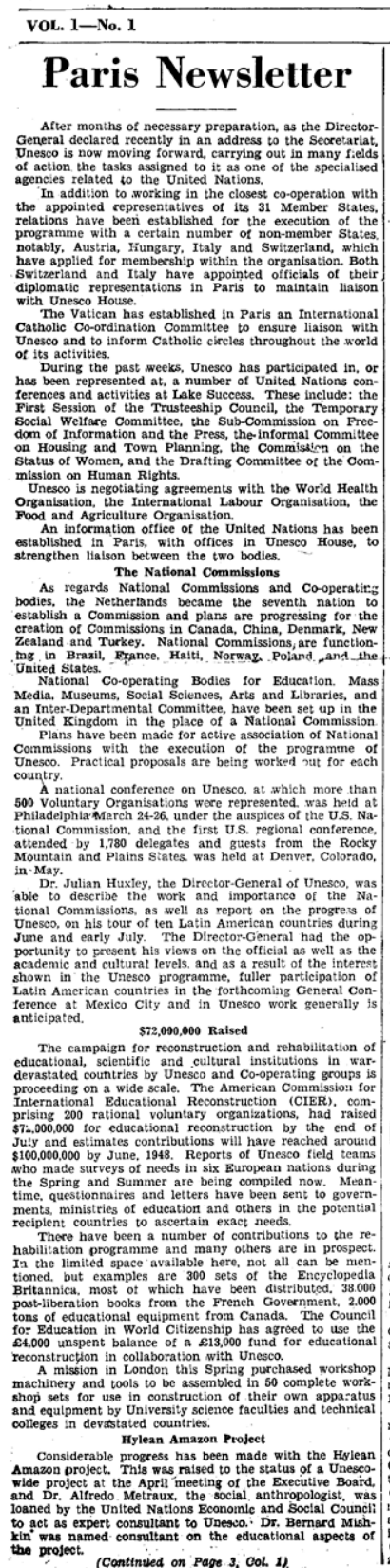

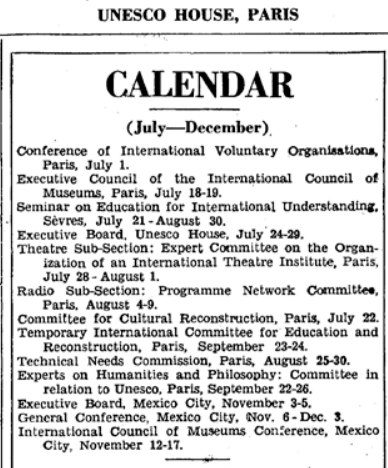

UNESCO Represented: international Union of Physics, International Union of
Chemistry, London, July 21-23. International Union of Biology, Copenhagen, July 28-29. International Union or Biology, Copenhagen, July 22-29,
international Congresso of Chemistry, London, July 17-25.
nternational Congress of Experimental Cytology, Stock.

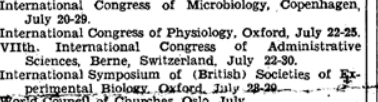
Worplac counent of Churches, Osio, July.
internat tonal Union of Local Authorities, Paris, July 7-12 Thternational Union of Local Authorities, Paris, July $7-12$,
International Students Service, Aarhus, Denmark, Juls. Worli rederation of Democratic Youth, Prague, July 20 -
August 17 .

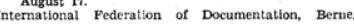
World Jewish Conference, Geneva or Paris. August.
W.F U N.A. Summer School, Geneva. August 3-10. W.F U N.A. Summer School, Geneva. August 3-10.
World Organisation of the 'Reaching Profession Giassow, Ausust 7-13.
International Fedieration of University Women, Toronto. World Federation of United Nations Associations,
Marienbad. August 18 . August 19.22
Aureau of Boy Scouts, Cháteau de Resny, International Union of Students, Paris, August 24-31.
International Festival of Documentary Films, Edin
Int burgh. August 31-September ?.
International Federation of Youth Hostels, Blaricum International Federation of Youth Hostels, Blaricum,
Holland, September 1.5. Sclentific Flims Association, Paris, September.
Friends' World Committe Associated Country Women of the World, Amsterdam, International Council of Women, Philadelphia, Sept. 5-12. International Congress of the History of Science, Latusanne, end of September.
International Academic Union, Brussels. Sept. $20-30$. World Young Women's Clat
October. United Jewish Educational and Cultural Organisation,
Paris, October 23-30.

\section{Executive Board}

THIRD SESSION

The Executive Board of Unesco convened in its third
sion July $24-29$ to hear a report by the Director-General ot developinents since its second meeting in April, to consider the 1948 program and deal with' administrative
financial and personnel matters The Board unanimousily voted to recommend to the
General Conference in Mexico City a budget not to exceed
59.000 .000 . The 1947 budget was $\$ 6,000.000$ 59,000.000. The 1977 budget was $\$ 6,000,000$
Several members of the Board, including Sir John Several members of the Board, including Sir. Joh
Maud (U...) and Dr. Rinhard Mckeon (U.S.A.). Com-
mended the way the organization had begun work on th 947 program.
Members of the Executive Board who took part in this

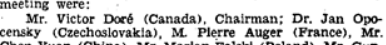
Chen Yuan (China), Mr. Marlan Falskil ( (Poland), Mr. Gun
tekin (Turkey), Mr. Kruyt (Netherlands), Sir John Maud

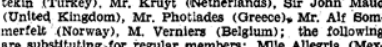

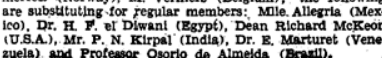

\section{UN-Unesco Accord}

Agreement Between the United Nations and

the United Nations Educational, Seientific and Cultural Organization

1-Article 57 of the Charter of the Untled Natione governmental agreement and having wide internationa responsibilities as defined in their basic instruments in
economic social cultural, educational, health, and related feconomic social, cultural, educationa, health, and related
fields, shall be brought into relationship with the United
Nations. 2-Articles $X$ and IV paragraph B, sub-paragraph of of
che constitution establishing the United Nations Educathonal, Sclentific and Cuitural Organization rétrvive that this Organization shall be brought into relation with tho
United Nations as soon as practicable, as one of the special. the United Nations with the function of advising the United Nations on the educational, sclentific and cultural Therefore the United Nations and the United Nations
zdueational, Scientific and Cultural Organization agree ARTICLE I

The United Nations recognizes the United Nations
Scientific and Cultural Organization (UNESCO) as a specialized agency responsible for taking such action as may be appropriate under its basic instrit-
ment for the accomplishment of the purposes set forth ARTICLE II AQMISSIOACF STATES NOT, MEMBELKS OR THE
UNITED NATIONS

Applications submitted by States not Members of the
United Nations for admission to the United Nations Edummediately transmitted by the secretariat of the Organzation to the Economic and Social Council of the United may recommend the rejection of such c.pplitiations and any such recommeadation shall be accepted by the Organiza
ation. If, within six months of the receipt of an applicaton by the Council, no such recommendation has been
to bertion made, the application shall be dealt with according to
Article II, Paragraph 2 . of the constitution of the Organ-
intion ARTICLE III

RECIPROCAL PEPBESETTATION

1-Representatives of the United Nations shall be in-
itted to attend the meetings of the General Conference of the United Nations Educational, Scientific and Cultura Organization and its committces, the Executive Board and
its committees, and such general, reglonal or other special meetings as the Organtzation may convene, and to partictp-
ate, without vote, in the delliberations of these bodies. 2-Representatives of the United Natlons Educational. attend meetings of the Economic and Social Council ar ot its commissions and committees and to participate.
withour vote, in the delliberations of these bodies r, ith re.

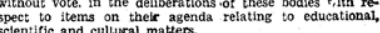
3-Representatives of the United Nations Educationsil, scientific and Culltral Organization shall be invited to attend meetings of the General Assembly of the United
Nations for the purposes of consultation on educational,
scientific and cultural matters. scientific and cultural matters.
4-Representatives of the United Nations Educationah
-Rention

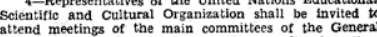
Assembly when educational, scientific or cultural matteri are under discussion, and to participate, without vote,
such discussions.
5 -Representatives of the United Nations Educational. 5-Representatives of the United Nations Educational,
scientific and Cultural Organization shall be invilied to attend the meetings of the Trusteeship Councill of the
United Nations and to partlcipate, without vote, in the deliberations thereof. with respect to ittems on the agends
relating to educational, scientlfic and cultural matters 6-Wrilten statements of the United Nations Educa-
onal. sclentific and Cultural Organization shall be distri-

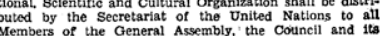
Members of the General Assembly, the Council and its
commissions, and the Trusteeshlp Council as appropriata. ARTICLE IV

PROPOSAL OF AGENDA ITEMS

Eubject to such preliminary consultation as may bo
necessary, the United Nations Educatlonal, selentufle and Cultural Organization shall tnclude on the agenda of the

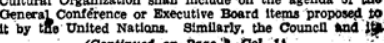
(Continued on Pape 2 cal. $u$.

Forside, UNESCO Monitor august 1947. UNESDOC, Digital Library. 
essayet fremhæver Dexter blandt andet de fire store forfatningsmålsætninger som blev vedtaget på UNESCOs 1. generalkonference: „1) Rehabilitation of shattered cultural and educational centers; 2) Reduction of illiteracy; 3) Revision of textbooks; and 4) Removal of barriers to world communications and extension of the use of the „mass media“. ${ }^{44}$ Derudover pegede Dexter også på vanskeligheder i det verdensomspændende samarbejde, herunder modsætninger mellem øst og vest. Essayet var ikke oprindelig skrevet til the Monitor, men var en sammenfatning af en artikel, der havde været bragt i American Quarterly Review tidligere samme år. Selv om UNESCO ikke stod som afsender og, som redakørerne bemærkede, derved ikke repræsenterede UNESCO officielt, var det ,a rather brilliantly presented view of Unesco as seen from the outside". ${ }^{45}$

Udover Dexters essay er det nærmeste vi kommer mere analyserende refleksioner over UNESCOs virke to tekster signeret af Julian Huxley (1887-1975), UNESCO første generaldirektør, i henholdsvis det andet og tredje nummer af the Monitor. I „Interim Report“ til FN’s økonomiske og sociale råd, ECOSOC, og „,The Report of the General-Director“", redegjorde Huxley for UNESCOs baggrund og aktiviteter i løbet af 1946-47, samt præsenterede overvejelser over organisationens fremtidige aktiviteter. ${ }^{46}$,,The reader will find below significant excerpts from the the full text", ${ }^{47}$ skrev redaktørerne i den ganske lange introduktion til Huxleys rapport, der i sin oprindelige udgave var på 95 sider, og i the Monitor altså fyldte hele to af tidsskriftets i alt fire sider.

Kun få illustrationer supplerede artiklerne i the Monitors tekstmættede sider, og både Dexters essay og Huxleys rapporter var forfattet i en politisk tone eller et policy-sprog, der har ganske store ligheder med den formidlingsform som er at finde i UNESCOs politiske styredokumenter. Selvom redaktørerne indledte „Paris Newsletter“ i en lidt lettere sprogtone end dét som ellers blev anvendt i the Monitor, var det samlet set policy-sproget som dominerede formidlingen. Det gjorde sig især gældende for uddragene fra generaldirektørens rapporter, der netop var uddrag og derved ikke omformet til det nye medie, som de blev bragt i. Til trods for at FN-organisationens budskab var flyttet fra ét medie til et andet (f.eks. fra generaldirektørens rapport til et tidsskrift henvendt til offentligheden) og at publikum nu var „the public“ - dvs. de intenderede læsere af the Monitor, ændredes den sproglige formidling sig således kun marginalt.

Det er enkelt at forestille sig, at den forestillede udbredelse af viden ikke nåede det tiltænkte publikum igennem the Monitor. Det samlede typografiske udtryk

\footnotetext{
44 Ibid., s. 3.

45 Ibid.

46 „Interim Report. Director-General's Account to ESCOSOC of Organisation's Activities Nov., 1946July, 1947“, UNESCO Monitor, oktober 1947, s. 1-4; Julian Huxley: 'Director-General Reviews $1^{\text {st }}$ Year. Report on Unesco Activities in 1947', UNESCO Monitor, november 1947, s. 1-4.

47 Julian Huxley: ‘Director-General Reviews $1^{\text {st }}$ Year. Report on Unesco Activities in 1947', UNESCO Monitor, november 1947, s. 1-4.
} 
sat i sammenhæng med den sproglige formidling, fordrede ikke udbredelsen af UNESCOs værdisæt, men må derimod ses som en forhindring for den ønskede vidensformidling og -cirkulation. At det ikke var den rigtige vej at gå, når der skulle kommunikeres med en bredere offentlighed, blev redaktionen da også hurtigt opmærksom på, og the Monitor udkom kun i tre udgaver fra august til november 1947, hvorefter the Courier overtog rollen som talerør til offentligheden.

\section{UNESCO Courier - et tidsskrift krydser grænser}

I slutningen af oktober 1947 begyndte den amerikanske journalist Sandy Koffler (1916-2002) at arbejde på the Monitor. Ifølge senere vidnesbyrd om Kofflers rolle i sammenhæng med nedlæggelsen af the Monitor og opkomsten af the Courier, var han manden som forstod, at the Monitors format ikke var den oplagte måde at nå en bredere offentlighed på. Knap en måned inde i sin ansættelse, forelagde Koffler derfor ,a proposal for a journal - with its editorial line and periodicity, an outline of its different sections, the number of columns on a page, the length of the articles, the typeface - to Harold Kaplan, the first Director of UNESCO's Bureau of Public Information“. ${ }^{48}$ Samlet set var der tale om et komplet udgivelsesforslag, som Koffler afleverede til Kaplan, og det følgende år blev arbejdet med the Courier iværksat, og dermed blev et af verdens første transnationale tidsskrifter født.

Gennem årene er det blevet et centralt kendetegn ved the Courier, at tidsskriftet blev udgivet på adskillelige sprog. Det skyldes ligeledes i høj grad Koffler, der havde forstået vigtigheden af at formidle på flere sprog. Selv talte Koffler ikke færre end syv forskellige sprog flydende - engelsk, fransk, spansk, portugisisk, italiensk, hebraisk og mandarin - og han var overbevist om, at „multiplying the number of language versions of the Courier was a way of building bridges between people“. ${ }^{49}$ Fra 1960'erne og fremefter udkom the Courier på blandt andet tysk (1960), arabisk (1961), japansk (1961) og hindi og tamil (1967) og da Koffler i februar 1977 gik på pension, blev the Courier udgivet på 15 sprog. 11 år senere, i 1988, kulminerede den sproglige mangfoldighed, da tidsskriftet blev udgivet på ikke færre end 35 forskellige sprog.

Den sproglige mangfoldighed var nødvendig i arbejdet med at kommunikere til og med en større del af verdens befolkning, hvis man ville nå længere ud end blot de øvre politiske cirkler. Målet var en meget bred læserskare, herunder navnlig på regionale og lokale niveauer i de enkelte lande. 


\section{$\widehat{\text { UNESCO }}$ \\ COUR I ER}

PUBLICATION OP THE UNITED NATIONS EDUCATIONAL, SCIENTIFIC AND CULTURAL ORGANISATION

\section{Volume 1- $-\mathrm{No}_{0} .1$ \\ 19 Avenue KLEBER - PARIS $16 \mathrm{C}$ \\ Conference Sets}

FEBRUARX 1948

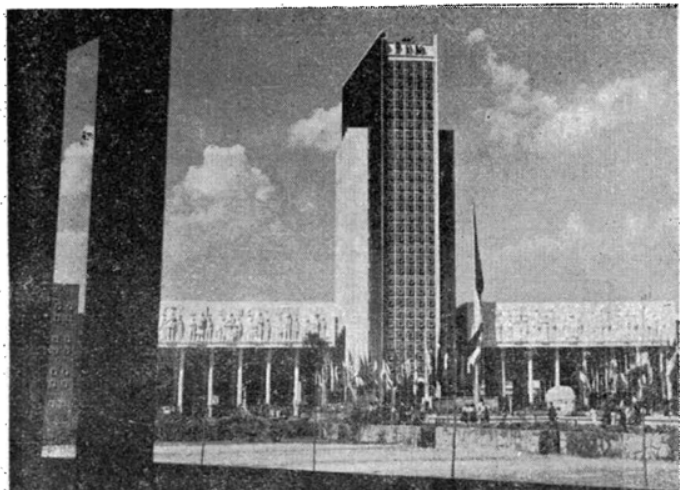

Dr Huxley Pays Tribute

\section{To Mexico}

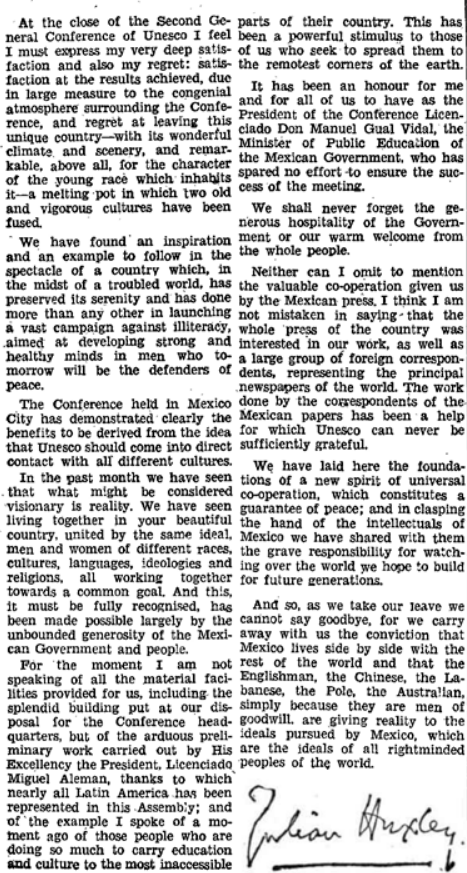

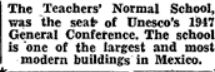

Programme

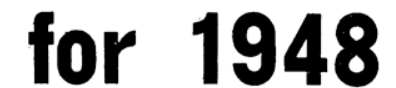

"UNESCO MONTH" ATTRACTS THOUSANDS

OF VISITORS TO MEXICAN CAPITAL

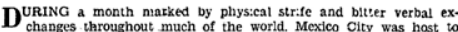
one of the most important efforts for peace and international under-
ontanding sinee the war: the Second Session of the Uresco General
stand Conference. F from forty member The school was buitt to house
Delegates

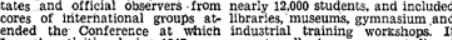

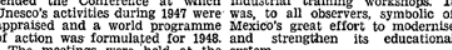
The meetings were held at the asstem
Escuela Nacional de Maestros" on The opening session of the conEscuela Nacional de Maestros" on The opening session of the Con-
the outskirts of Mexico City. an ference was. held in the resplenden
littra-modern

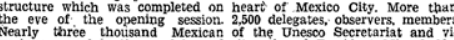
Corkmen and artisans laboured sitors heard Presicent Miguel Ale
hroughout the nifsta of November man of Mexico welcome the Con-6 to prepare the school for use as ference, and sound a solemn note
he sitte of an international con- of warning which was the reenot

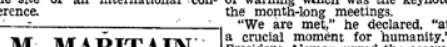

\section{MARITAIN}

CALLS FOR UNITY The text of the Unesco Appeal are an stumbling block to interna With this issue we begin
the publication of Unesco as placed before the Giumeral the work of Unesco in the field
onference by the President of
to becation, Science and culture on the way to developing Conference by the President of to be on the way to developing and
he French Delegation, M. Jacques
strengthening the moral spirit of Courier, a periodical designed to in form the public of
the activities of the Spectalised Agency of the United

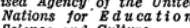
Sclence end Culture.
The Unesco Monitor Renoeforth be reserved for the publication of of fiction
texts, resolutions and proThis itrst issue of Unesce
zourler is devoted entirely
to the woork of the recent to the work of the recen
General Conference of $U_{n-1}$ esco, held in Mexico ${ }^{C}$ itt
between November 6 and programe. adopted for

Highlights of Projects and Budget for $2^{\text {nd }}$ Year The Second Session of Unesco's buaget. This innovation enablec
General Conference was the first the working parties and the Pro

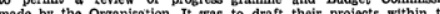
the first opportunity for Uneseo budgetary limits designated. Th to weigh its development with the final budget, as ultimately adopth
measure of actual experience. It was also the first Unesco Con
Conference to be held away from 637 .

the headquarters in Parls, which The 1948 Unesco programme
fact gave rise to many complex subject of detailed study and dis and delicate problems. At the cussion at the Conference, wa 列 of peace-convened during inter- as follows:

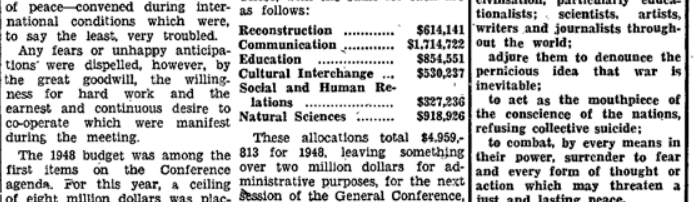
doing so much to carry education

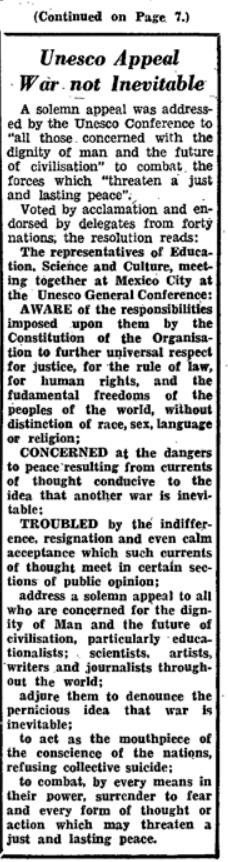

Forside, UNESCO Courier februar 1948. UNESDOC, Digital Library. 
I februar 1948 udkom den første udgave af the Courier. Sammenlignet med tidens andre blade og tidsskrifter skilte det første nummer sig ikke nævneværdigt ud. Med sit otte sider lange avisformat, illustreret med små sort-hvide fotos, havde tidsskriftet et noget simpelt, ja måske endda ganske kedeligt layout i forhold til, hvad der faktisk var muligt rent trykketeknisk sidst i 1940'erne. ${ }^{50}$ I begyndelsen udkom the Courier en gang om måneden på tre forskellige sprog - engelsk, fransk og spansk. Prisen for et halvårsabonnement var $0,5 \$$ - svarerende til ca. 35 kr. i dag. Tidsskriftet blev solgt via abonnementsordning, men det var også tilgængeligt f.eks. på offentlige biblioteker. I hver udgivelse gjorde en lille indrammet boks opmærksom på, hvor læserne i de enkelte lande kunne finde den nationale distributør med henblik på at tegne abonnement, samt til hvilke priser. ${ }^{51}$ I Danmark skulle man gå til Forlaget Einar Munksgaard, Nørregade 6, i det centrale København, mens f.eks. svenskerne, selvom de endnu ikke var medlem af UNESCO, kunne købe bladet hos O.E. Fritzes, der meget symbolsk lå på Fredsgatan 2 i Stockholm. ${ }^{52}$

I løbet af ganske få år ændrede the Courier imidlertid sit typografiske udtryk. Avisformatet blev udskiftet til fordel for et mindre og mere praktisk format med flere fotos, og tidsskriftet blev fra 1954 trykt i farver, ligesom underoverskriften „A window open on the world“ blev tilføjet. Samtidig med det forandrede layout voksede tidsskriftet også i oplag og læsere, som den engelske antropolog Alan Tormaid Campbell har beskrevet det i forbindelse med 70-året for the Courier: „In 1949, 40,000 copies of the magazine were produced; this figure rose to 500,000 by the beginning of the 1980s. It was estimated that each copy would be read by more than four people, which meant that the Courier had a readership of over two million“. ${ }^{53}$ Det er imidlertid en noget spekulativ beregning, og nøjagtig hvor stor en læserskare tidsskriftet rent faktisk har haft er vanskeligt at bestemme.

Det samme gælder i forhold til at finde frem til, hvem som egentlig læste et tidsskrift som the Courier. Tidsskriftets tilgængelighed på f.eks. offentlige biblioteker i Skandinavien, kan give et lille indblik i, hvilke muligheder der var for at få tilgang til det uden abonnement. Derudover har the Courier i forbindelse med sit 70-års jubilæum publiceret enkelte vidnesbyrd af personligheder som Nelson Mandela og Roberto Markarian, matematiker og tidligere rektor ved Universidad de la República i Uruguay. Begge fortæller om, hvordan og hvorfor de læste tidsskriftet. ${ }^{54}$

50 Sammenligner man det typografiske udtryk med blade og tidsskrifter udgivet i samme periode, og tager i betragtning, at det var en verdensomspændende organisation, som stod bag the Courier, kan det med eftertidens øjne, synes overraskende, at man målgruppen taget $\mathbf{i}$ betragtning, havde et så simpelt layout i tidsskiftets første år.

51 Se f.eks. Unesco Courier, februar 1948, s. 8;

52 Unesco Courier, februar 1948, s. 8; Unesco Courier, november 1955, s. 41.

53 Campbell 2018.

54 Markarian 2018. 
De to udsagn er ikke repræsentative for the Couriers læsere generelt, men Markarian har dog beskrevet, hvordan han i sine unge år i 1950'erne læste the Courier og hvilken betydning det havde for hans dannelse: „Between the ages of 12 and 17, I regularly read the UNESCO Courier and that is how I absorbed culture. I can still see the images on the magazine's covers, and so many questions that shook the world of science, culture, and education in the past century come back to mind“. ${ }^{55}$ Markarian voksede op i en analfabetisk familie i et fattigt kvarter i Montevideo, men at læse the Courier blev en del af hans uddannelse og gjorde det muligt at „look through an open window onto the world“,56 som han så poetisk har beskrevet sin læsning. Markarians læserudsagn er blot et enkelt, men det viser, at en selvstændig undersøgelse af vidnesbyrd fra the Couriers læsere, vil kunne bidrage yderligere til forståelsen af, hvordan tidsskriftet er blevet læst, af hvem og hvilken videnscirkulation det har bidraget med, samt give indsyn i den betydning som en del af UNESCOs arbejde med at nå såkaldte almindelige mennesker har haft. ${ }^{57}$

The Courier blev udgivet helt frem til 2001, hvor den faste månedlige publikation ophørte. Herefter blev det udgivet mere sporadisk, i nogle år mere regelmæssigt end i andre, indtil 2011, hvor manglende finansiering betød, at tidsskriftet blev nedlagt helt. Seks år senere, i april 2017, blev the Courier imidlertid genoplivet med markant finansiel støtte fra Kina under mottoet „Several Voices, One World“. ${ }^{58}$ Bortset fra udgivelsespausen i begyndelsen af årtusindskiftet, er the Courier således blevet udgivet kontinuerligt siden 1948. Den sproglige mangfoldighed er bevaret - om end i reduceret form, og i dag er den månedlige publikation tilgængelig på seks forskellige sprog; arabisk, kinesisk, engelsk, fransk, russisk og spansk. Det er stadig muligt at få fat i en papirudgave, men tidsskriftet er dog fortrinsvis udbredt i sin digitaliserede form. ${ }^{59}$

55 Ibid.

56 Markarian 2018,

57 En anden måde at undersøge the Couriers udbredelse kan gøres gennem det statistiske materiale som blandt andet findes i UNESCOs digitale arkivkatalog 'AtoM'. Her er det eksempelvis muligt at undersøge, hvor mange som i dag læser og/eller orienterer sig i de ældre digitaliserede udgaver af the Courier i „Monthly Report on the Use of UNESCO Public Information Products“. I top-10 over de mest konsulterede pdf'er i UNESCO.DOC, kan man blandt andet læse at the Couriers temanummer om The Ramayana and the Mahabharata: two epics of Asia, fra december 1967 med sine 2698 'views' var det syvende mest sete UNESCO-dokument i september 2012, ligesom der findes forholdsvis detaljeret statistik om antal downloads af de mest populære artikler og temanumre nye, som gamle. Yderligere information om downloads af UNESCOs nyere udgivelser, kan findes ved søgninger i UNESCO Archives AtoM Catalogu, https://atom.archives.unesco.org/ Roberto 2018.

59 Courier, 'About' https://en.unesco.org/courier/about, (besøgt 20/3 2019); The Courier, Archives: https://en.unesco.org/courier/archives (besøgt 1/12 2019). 


\section{Fra officielle dokumenter til farverigt tidsskrift}

I og med the Courier blev udgivet af en verdensomspændende organisation, var dets potentielle modtagere ganske omfattende sammenlignet med andre udgivelser i tiden. Men ved udgivelsen gjorde redaktionen ikke noget særligt ud af, at det første nummer af tidsskriftet var på gaden. Februar-nummeret omhandlede næsten udelukkende UNESCOs 2. generalkonference, der fandt sted i Mexico City i november og december året før, ,,at which Unesco’s activities during 1947 were appraised and a world programme of action was formulated for 1948“. ${ }^{60}$ Artikel efter artikel behandlede systematisk de forskellige initiativer inden for organisationens kernepunkter og kun en lille notits på forsiden gjorde læseren opmærksom på, at det var første nummer af et internationalt tidsskrift. ${ }^{61}$ En årsag til den sparsomme opmærksomhed handlede sandsynligvis om, at the Courier ikke var den første UNESCO-publikation som havde til hensigt at nå offentligheden, samt at redaktionen kan have betragtet udgivelsen som en forlængelse og/eller udvikling af the Monitor, og dermed ikke som en ny og selvstændig publikation, hvilket også det umiddelbart identiske layout vidnede om.

Selv om der layoutmæssigt var ganske mange ligheder med forgængeren, kunne læseren allerede i de første numre af the Courier observere et skifte i forhold til, hvordan the Monitor havde henvendt sig til sit publikum. Først og fremmest blev sideantallet fordoblet og de lange essays og rapporter over organisationens aktiviteter blev forsynet med langt flere fotos og andre typer af illustrationer i form af tegninger og andre grafiske virkemidler, som f.eks. underoverskrifter, forskellige skriftstørrelser og typer. Alt sammen noget som gav et mere levende typografisk udtryk og som var med til at lette læsningen af the Courier sammenlignet med forgængeren. At være rigt illustreret blev således langsomt men sikkert en central del af tidsskriftets kommunikationsform.

Selv om artiklerne, præcis som i the Monitor, kredsede om UNESCOs kernepunkter og formidling af organisationens aktiviteter, var det tydeligt, at der hos redaktørerne nu var en anden bevidsthed om, hvad tidsskriftets tiltænkte målgruppe krævede. I the Couriers første år bevægede redaktionen sig efterhånden mere og mere væk fra det policy-sprog, som ellers havde kendetegnet the Monitor, og sammen med det øgede antal illustrationer stod den mere levende formidling i kontrast til forgængerens sprogform. Samtidig blev artiklerne om UNESCOs aktiviteter suppleret med mindre opslag om eksempelvis arkitektur, historie eller nye opfindelser.

Januar-nummeret fra 1950 er et godt eksempel på den forandring, som the Courier gennemgik materielt og tekstuelt. På hver eneste side spiller illustrationerne

60 Unesco Courier, februar 1948, s. 1.

61 Ibid. 
sammen med de øvrige typografiske virkemidler en vigtig rolle i tidsskriftets formidling. ${ }^{62}$ Indledningerne til artikelteksterne er indrammet eller fremhævet med fed typografi. Paratekster som forfatternavne, underoverskrifter eller billedtekster er markeret på forskellig vis, og er derigennem med til at bryde artikelteksterne op og gøre læsningen mere smidig. Tekstuelt er der både kortere og længere artikler; de tekstmættede afrapporteringer fra UNESCO-møder og aktiviteter er fortsat tilstede, men de er suppleret med artikler om eksempelvis kunst og kultur, ligesom også UNESCO-rapporter formidles i en omarbejdet form. Et enkelt eksempel er artiklen „A Child’s Education Begins Twenty Years Before He Is Born“, hvor redaktionen i indledningen gør opmærksom på, at artiklen tager afsæt i en rapport udarbejdet af UNESCO-konsulenten Jeanne Chaton. ${ }^{63}$

Den tre spalter lange artikel henviser kortfattet til FNs og UNESCOs officielle retningslinjer på området, ligesom der i selve artiklen er placeret en tekstboks med titlen ,The Declaration of Women's Right to Education and Culture Becomes a Rallying Gry“, hvor et kort uddrag af den tidligere generaldirektør Jaime Torres Bodets (1902-74) tale i forbindelse med the Conference on Obstacles to Equality or Educational Opportunities for Women, blev bragt. ${ }^{64}$ Artiklen giver nogle konkrete retningslinjer, der efter al sandsynlighed er omskrevet fra Chatons rapport, til hvilke metoder UNESCO skulle anvende i arbejdet med at opnå forfatningstekstens målsætning om ,the realization of educational equality for the sexes“. ${ }^{65}$ Her peger artiklen blandt andet på vigtigheden af, at UNESCO samarbejder med og lytter til anbefalinger fra FN-kommissionen Status of Women og at organisationen „must also follow closely the policy of Member States with regard to general education, schools and universities“. ${ }^{6}$

Et andet eksempel på hvordan UNESCO-resolutioner blev formidlet i en ny form i the Courier, er den helt korte artikel „Countries answer UNESCO call for lifting of barriers to knowledge“ fra februar 1951. ${ }^{67} \mathrm{I}$ en kort indledning bliver det forklaret, at der på den 5. generalkonference i Firenze blev vedtaget 11 resolutioner i forhold til at fremme „the free flow of information“, hvorefter flere landes konkrete initiativer i forhold til resolutionerne listes op. Af listen fremgår det blandt andet at „Denmark is negotiating a newspaper exchange with Austria, Italy and West Germany“, „Canada has granted duty-free entry to certain educational film“, og at „Colombia has granted duty-free entry to all Unesco books, publications and other educational, scientific and cultural materials consigned

62 Unesco Courier, januar 1950.

63 „A Child's Education Begins Twenty Years Before He Is Born“, Unesco Courier, januar 1950, s. 9.

64 Unesco Courier, januar 1950, s. 9; Jaime Torres Bodet afløste Julian Huxley som generaldirektør for UNESCO og sad på posten i perioden 1948-52.

65 Unesco Courier, januar 1950, s. 9.

66 Ibid., s. 9.

67 Unesco Courier, februar 1951, s. 12. 
to approved institutions“. ${ }^{68}$ I stedet for blot at indsætte den uredigerede resolutionstekst, oversættes budskabet i en forenklet form og konkretiseres efterfølgende i initiativer taget af de enkelte medlemslande. I den blot én spalte lange artikel fremhæves de forskellige konkrete initiativer gennem det typografiske udtryk, ved blandt andet at markere de enkelte lande med fed skrifttype, ganske stor linjeafstand, samt ved at have stjernesymboler imellem beskrivelserne af de enkelte landes tiltag.

Sammenlignet med de øvrige af UNESCOs kernepunkter, fik uddannelse og kommunikation en væsentlig i plads i the Courier - især i tidsskriftets første år. Programmet for fundamental uddannelse blev ofte omtalt, ligesom mange andre initiativer og aktiviteter på uddannelsesområdet blev formidlet tekstuelt, men især igennem tidsskriftets illustrationer. UNESCOs idéer og idealer på uddannelsesområdet blev udtrykt på vidt forskellige måder i the Courier. I deres bevægelse fra et officielt dokument som forfatningsteksten til artiklerne i tidsskriftet fandtes således en tydelig videnstransformation. Som eksemplificeret med januar-nummeret i 1950 blev indholdet i forfatnings- og resolutionstekster, samt rapporter, omarbejdet og formidlet i en mere spiselig form, end den som først blev anvendt i the Monitor, hvor eksempelvis generaldirektørens rapporter blev bragt i en ubearbejdet form.

Som tidsskrift fik the Courier opmærksomhed. Der blev henvist til de forskellige temanumre eller artikler i så forskelligartede tidsskrifter som Journal of the International Folk Music Council, The Mathematics Teacher eller Geographical Review, ligesom også enkelte numre blev omtalt eller anmeldt. ${ }^{69}$ The Courier havde altså verdens bevågenhed og indgik som en del af den offentlig debat.

\section{Fra hensigt til handling}

Kvinders og pigers adgang til uddannelse, eller mangel på samme, var et aspekt af uddannelsesområdet som UNESCO havde sin opmærksomhed rettet mod. En gennemgang af organisationens programerklæringer fra 1945 til 1975 viser, at UNESCO fra begyndelsen havde blik for de kvindepolitiske spørgsmål på uddannelsesområdet, og i løbet af de tre første årtier vedtog UNESCOs medlemslande et større antal resolutioner og henstillinger på området. ${ }^{70}$

Ved hver generalkonference siden 1947 blev der vedtaget mindst én resolution, som specifikt rettede sig mod problematikker, som vedrørte pigers og kvin-

68 Ibid.

69 Se f.eks. Journal of the International Folk Music Council, 1956:8), s. 103; The Mathematics Teacher, april 1967:60/4, s. 382; Geographical Review, april 1967:57/2, s. 280-281.

70 Programerklæringerne er en sammenfatning af de erklæringer som UNESCO-medlemsstaterne beslutter at arbejde henimod. Se også Simonsen 2007. 


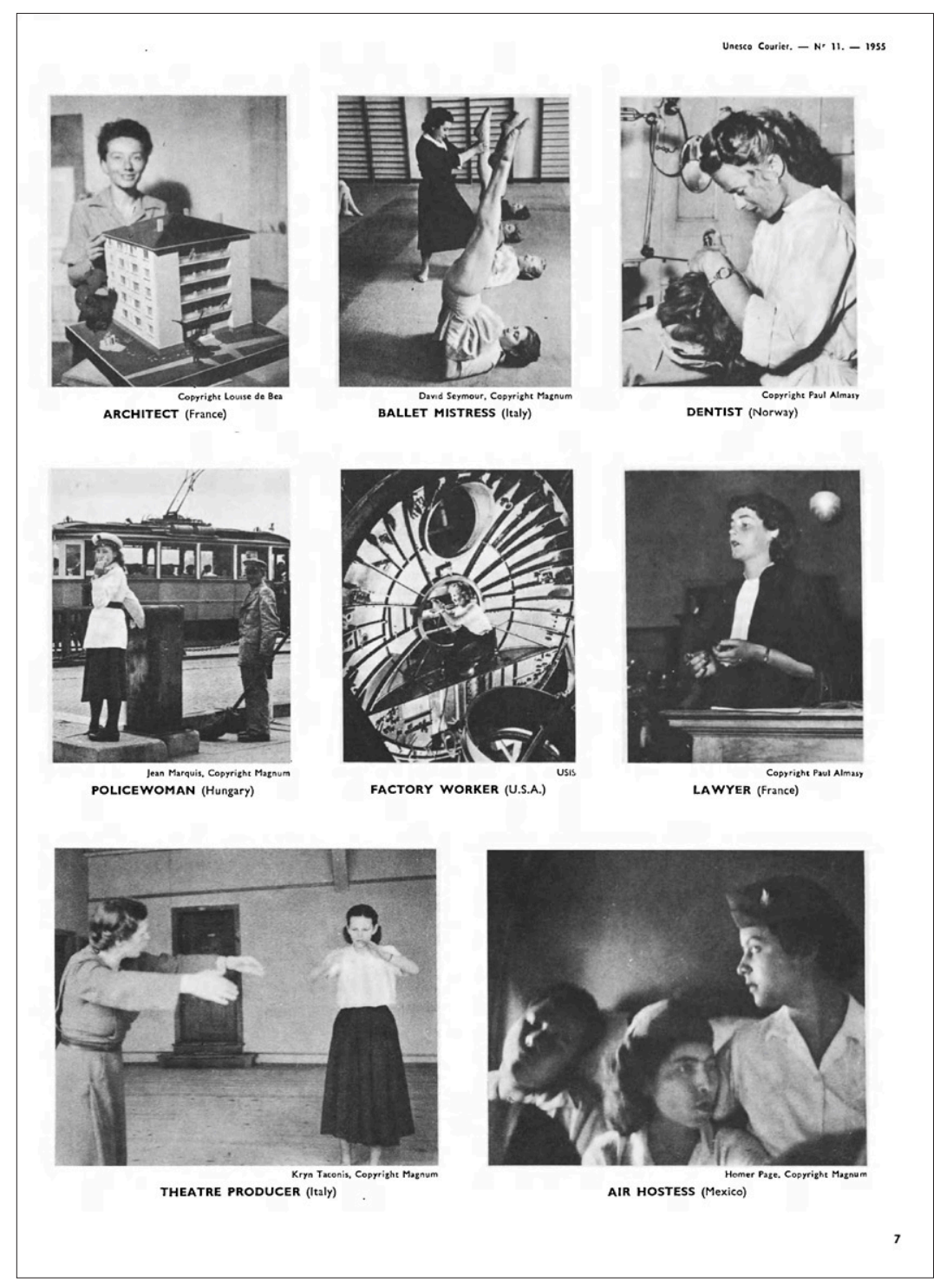

UNESCO Courier november 1955, s. 7. UNESDOC, Digital Library.

ders uddannelsesmuligheder. Resolution 3.18 fra UNESCOs 2. generalkonference i Mexico City i 1947 var den første generalkonferencetekst, udover forfatningen, som eksplicit henstillede til initiativer, hvis mål var at fremme kvinders uddannelsesmuligheder: „The Director-General is instructed to collaborate with the Commission on the Status of Women of the Economic and Social Council of the United Nations in promotion enquiries, through competent bodies, into educatio- 


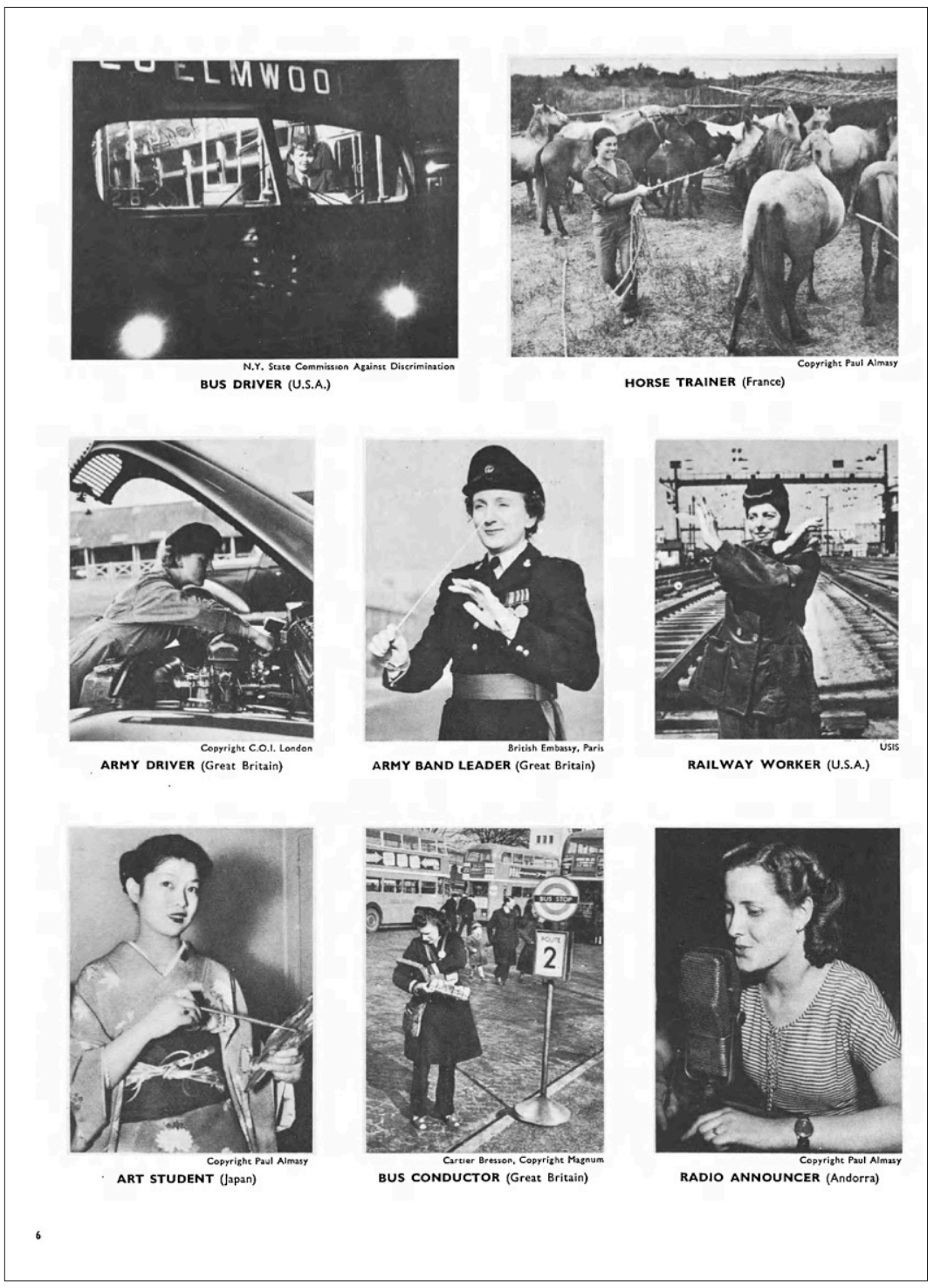

UNESCO Courier november 1955, s. 6. UNESDOC, Digital Library.

nal opportunities to women“. ${ }^{71}$ Efter 1950 skete der en udvidelse og specificering af de kvindepolitiske resolutioner og generalkonferencens delegerede henstillede i programerklæringen for 1952 ikke længere blot generaldirektøren, men også de enkelte medlemslande til at udvikle mulighederne for kvinders adgang til uddannelse. I resolution 1.25 stod der blandt andet, at medlemsstaterne var ,invited to

71 Resolutions, The Programme of Unesco in 1948, I Resolutions 2nd General Conference 1947 (2/19:2C/Res.), s. 22 (UNESCO Archives). Ved de efterfølgende generalkonferencer i Beirut (1948) og i Firenze (1950) blev resolutionen genbrugt og med omtrent samme formuleringer vedtaget som resolutionerne 2.17, 2.76 og 2.133. Resolutions, Programme for 1949: I Resolutions 3rd General Conference 1948 (3/29:3C/Res.) s. 20; Resolutions, Programme for 1950: I Resolutions 4th General Conference 1949 (64/38:4C)/Res.), s.18. 
undertake or to develop the education of women for citizenship, especially in countries where women have recently won political rights“. ${ }^{72}$

I de første numre af the Courier blev spørgsmålet om kvinders adgang til uddannelse primært omtalt i generelle vendinger, ofte i forbindelse med en samlet behandling af emnet, men den øgede opmærksomhed på det politiske niveau afspejlede sig også i tidsskriftet. I de første år dog primært gennem illustrationerne, mens det var sparsomt med artikler som havde spørgsmål om kvinder og uddannelse som selvstændigt tema. En undtagelse er artiklen „An Indian View. The Place of Women in Unesco“ af Rajkumari Amit Kaur, som indgik i November-nummeret i $1948 .^{73}$

Langsomt men sikkert blev spørgsmålet imidlertid behandlet mere selvstændigt i flere og flere artikler. I anledningen af Human Rights Day i november 1955, havde the Courier et temanummer med titlen „Are Women Inferior Beings?“. ${ }^{74}$ I lederen henviste redaktionen til UNESCOs forfatningstekst, herunder forpligtelserne til at fremme lige uddannelsesmuligheder for begge køn, hensigten med forfatningen og dens anbefalinger, samt vejen til at opnå de opstillede mål. Temanummeret igennem blev der givet talrige eksempler på kvinders potentiale i forhold til at deltage i alle dele af samfundet, ligesom fremskridt i forhold til kønnenes ligestilling også blev pointeret gentagende gange. ${ }^{75}$ En to sider lang billedudstilling, hvor kvinder udøvede diverse arbejdsopgaver som f.eks. buschauffør, hestetræner, leder af militærorkester, tandlæge og teaterinstruktør fremstod mellem de øvrige tekstligt orienteret artikler som et stærkt budskab. ${ }^{76}$

Op igennem 1950' og -60'erne fortsatte UNESCO arbejdet med at forfine de politiske styredokumenter. Med vedtagelsen af den omfattende uddannelseskonvention The Convention against Discrimination in Education markeredes i 1958 et skifte i UNESCOs kvindepolitiske prioritering. Spørgsmålet om kvinders uddannelsesmuligheder var kommet endnu højere op på dagsordenen via inddragelsen i konventionen. Overordnet var der stor kvindepolitisk aktivitet både i FN og UNESCO. Aspektet blev indarbejdet i de mange konventioner, anbefalinger og resolutioner, som organisationerne vedtog i perioden. Udviklingen i UNESCO-erklæringerne er tydelig: Op gennem 1960'erne og i første halvdel af 1970'erne blev UNESCOs resolutioner om kvinder og uddannelse ikke blot mere og mere fyldige, men også særdeles specifikke, og i FN-regi kulminerede det kvindepolitiske arbejde med vedtagelsen af the Declaration on the Elimination of Discrimination Against Women i $1967 .{ }^{77}$ Det øgede fokus kom også til udtryk i the Courier, som

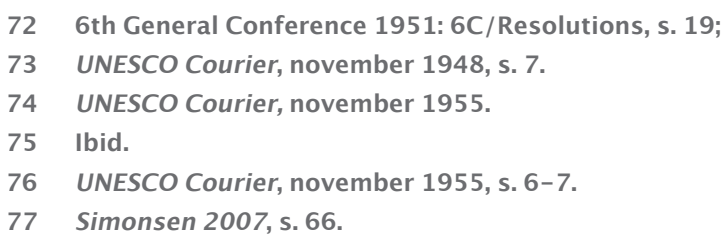


forsatte med at synliggøre den kvindepolitiske dagsorden igennem det tekstlige indhold, men særdeleshed via illustrationerne op igennem 1960'erne.

1975 blev af FN udråbt til internationalt kvindeår, der samtidig også var startskuddet til FN's kvindeårti, 1975-85. Det var FN-kommissionen Status of Women, der havde foreslået lanceringen af kvindeåret. Tanken bag initiativet var at samle op på, hvad FN-systemet havde opnået på det kvindepolitiske område i de forgangne år, og på baggrund af resultaterne vurdere i hvilken retning arbejdet kunne fortsætte. Udover at samle op på indsatserne i FN-regi var hensigten med kvindeåret at øge opmærksomheden på aktuelle kvindepolitiske spørgsmål. Herunder også forfatningsidealet om lige uddannelsesmuligheder for alle uanset race, køn og sociale og økonomiske forskelle. ${ }^{78}$.

I løbet af 1975 markerede the Courier kvindeåret med to temanumre i henholdsvis marts og august-september (to måneder i ét) som formidlede UNESCOs idealer/værdier i forhold til piger, kvinder og uddannelse på flere forskellige måder. I årets første numre af the Courier mærkede læserne dog ikke meget til, at det var internationalt kvindeår. De øvrige udgivelser i løbet af 1975 havde forskellige temaer i fokus. I løbet af 1950'erne var redaktionen begyndte at behandle særskilte fokusområder i de enkelte numre. I stedet for at bringe et sammensurium af diverse UNESCO- indsatser og -aktiviteter var hvert enkelt nummer dedikeret til ét eller to særlige temaer. I januar-nummeret blev kvindeåret således ikke nævnt med ét ord, mens det i et tillæg til februar-nummeret, „Special Unesco Courier Supplement“, blev omtalt i forbindelse med en artikel, hvor udvalgte dele af generaldirektør Amadou Mahtar M’Bows' (1921-) tale ved generalkonferencen i Paris i november 1974, blev bragt. ${ }^{79}$ Derimod blev hele marts-nummeret dedikeret til kvindeåret og her blev blandt andet idealet om lige uddannelse fremhævet som centralt i forhold til at skabe et mere ligestillet verdenssamfund. ${ }^{80}$

\section{Afslutning}

UNESCOs mission om at etablere en fredelig og demokratisk verden har i årenes løb udmøntet sig igennem en mangfoldighed af initiativer på forskellige niveauer. Sammen med UNESCOs forfatning har resolutioner vedtaget på generalkonferencer, og rapporter udarbejdet i UNESCOs hovedkvarter, haft til hensigt at påvirke forskellige politiske niveauer, mens mere nationale og lokale initiativer sigtede mod at cirkulere UNESCOs idéer og idealer igennem forskellige udgivelser. I arbejdet med at udbrede UNESCOs verdenssyn og ,ændre tankegangen hos men-

78 UNESCO: Constitution of the United Nations Educational, Scientific, and Cultural Organization. Adopted in London on 16 November 1945, Article 1, 'Purposes and Functions'. 


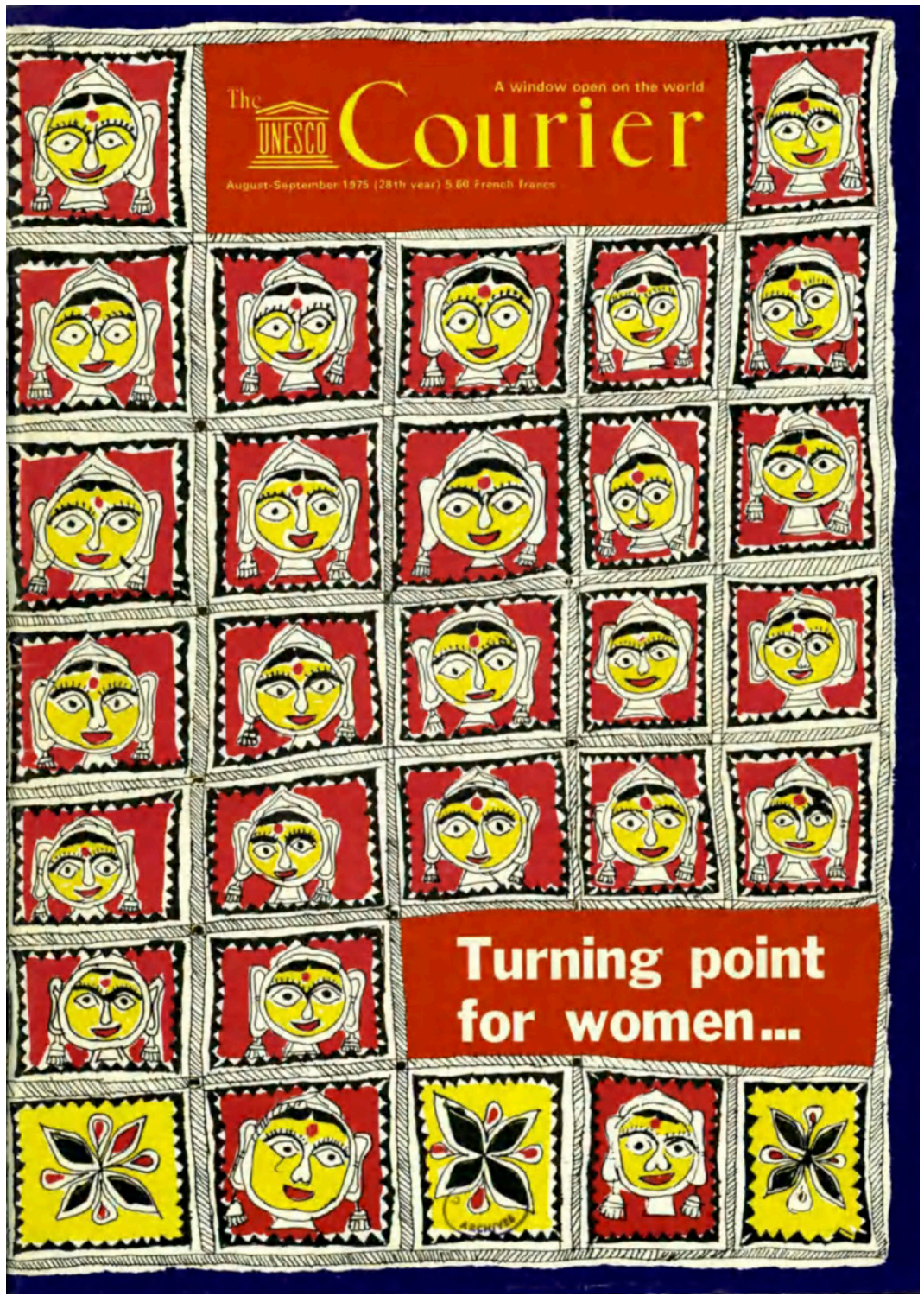

Forside, UNESCO Courier aug.-sep. 1975. UNESDOC, Digital Library.

nesker overalt på kloden“, ${ }^{81}$ spillede initiativer i forhold til kommunikation generelt, og massekommunikation i særdeleshed, en væsentlig rolle. Udgivelserne the Monitor og the Courier var to af flere initiativer i UNESCOs tidlige kommunikationsstrategi, der skulle formidle FN-organisationens værdisæt og derved være medvirkende til at cirkulere idéer og idealer som kunne skabe ,peace in the minds of men“ .82

81 Duedahl 2015, s. 34.

82 UNESCO: Constitution of the United Nations Educational, Scientific, and Cultural Organization. Adopted in London on 16 November 1945, Præamblen; Duedahl, 2016, s. 3. 
I artiklen har jeg givet enkelte eksempler på videnstransformation og -cirkulation med særlig fokus på idealet om pigers og kvinders muligheder på uddannelsesområdet. I takt med at antallet af resolutioner i de politiske styredokumenter øgede, steg også omtalen og formidlingen af kvinders uddannelsesmuligheder og rettigheder i the Courier i form af selvstændige artikler, men også i hele temanumre som var dedikeret til diskussioner om kvinders samfundsmuligheder. Inden de artikler og temanumre fik plads i the Courier, blev idealet imidlertid formidlet gennem illustrationerne. Billeder af piger og kvinder i undervisningssituationer, i færd med at læse eller skrive eller lære sig anden praktisk uddannelse ude som hjemme, fik stor plads blandt tidsskriftets illustrationer.

Ved at kombinere det boghistoriske kommunikationskredsløb med det videnshistoriske cirkulationsbegreb, har jeg forsøgt at vise nyttigheden af at bringe de to forskningsfelter i spil i fællesskab. Det boghistoriske perspektiv er især blevet anvendt til at vise materialitetens rolle og betydning for videnstransformationen og -cirkulationen, når en organisation som UNESCO forsøger at nå udover et politisk niveau og formidle til en større almenhed. I studiet har jeg begrænset det empiriske fokus til UNESCO-tidsskrifter, men det er en undersøgelse som med fordel kan suppleres med andre typer af UNESCOs publikationer i videre forskning.

\section{Kilder}

UNESDOC, Digital Library:

UNESCO Monitor 1947-1948.

UNESCO Courier 1948-1975.

\section{UNESCO Archives, Paris:}

General Conference Documents, Resolutions and recommendations:

The Programme of Unesco in 1948, Resolutions 2nd General Conference 1947

(2/19:2C/Res.).

Resolutions, Programme for 1949, Resolutions 3rd General Conference 1948

(3/29:3C/Res.).

Resolutions, Programme for 1950, Resolutions 4th General Conference 1949 (64/38:4C)/Res.).

Resolutions. Programme for 1951, Resolutions. 5th General Conference 1950. s. 32-36. (5/46: 5C/ Res.).

Resolutions. Programme Resolutions 1952, Resolutions. 6th General Conference 1951. s. 17-24. (6/57: 6C/ Res.).

Resolutions. Programme Resolutions 1953-54, Resolutions. $7^{\text {th }}$ General

Conference 1952. s. 16-25. (7/67: 7C/ Res.). 
Resolutions. Programme for Unesco for 1955-56: Education, Resolutions. 8th General Conference 1954. s. 25-27. (8/80: 8C/Res. and Annexes.).

Resolutions concerning the Programme and Budget. Programme for UNESCO for 1957-68: Education, Resolutions and recommendations. 9th General Conference 1956. s. 11-12:90.

(9/192: 9C/Res.).

Programme and Budget for 1959-60: Education, Resolutions and recommendations. 10th General Conference 1958. (10/104 :10C/Res.).

Programme and Budget for 1961-62: Education, Resolutions and recommendations. 11th General Conference 1960. s. 19-20. (11/117: 11C/ Res.).

Convention Against Discrimination in Education, Resolutions and recommendations. 11th General Conference 1960. s. 119-122. (11/117: 11C/ Res.).

Programme and budget for 1963-1964: Education, Resolutions and recommendation. 12th General Conference 1962. s. 10-32. (12/130: 12C/ Res.).

Programme and budget for 1965-1966: Education. I Resolutions and recommendation. 13th General Conference 1964. s. 9-30. (13/144:13C/Res.).

Resolutions and recommendations: Programme and budget for 1969-1970. Education. 15th General Conference, Paris 1968 Paris. s.16-30: s. 21. (15/174 15C /Res. Vol I.).

UNESCO Archives database Access to Memory (AtoM) (Online):

Constitution of the United Nations Educational, Scientific, and Cultural Organization. Adopted in London on 16 November 1945.

\section{Illustrationer}

UNESDOC, Digital Library:

UNESCO Monitor, august 1947, forside.

UNESCO Courier, februar 1948, forside.

UNESCO Courier november, 1955, s. 6-7.

UNESCO Courier, marts 1975, forside

\section{Litteratur}

Adams, Thomas R. \& Nicolas Barker. 2001. A Potencie of Life: Books in Society; The Clark Lectures, 1986-1987. Oak Knoll Press.

Bjerring-Hansen, Jens \& Torben Jelsbak (reds.). 2010. Boghistorie. Aarhus: Aarhus Universitetsforlag.

Bjerring-Hansen, Jens. 2015. Ludvig Holberg på bogmarkedet. Studier i Peder Paars og den litterære kultur i 1700- og 1800-talet. København: Museum Tusculanums Forlag. 
Boel, Jens. 2016. »UNESCO’s Fundamental Education Program, 1946-1958: Vision, Actions and Impact. « I A History of UNESCO. Global Actions and Impacts, af Poul (ed.). Duedahl, 153-167. Springer.

Campbell, Alan Tormaid. 2018. „The UNESCO Courier is 70! An inspiring read. https://en.unesco.org/courier/january-march-2018/unesco-courier-70inspiring-read“.

Cassam, Annar. 2018. „The UNESCO Courier is 70: The only journal Nelson Mandela read on Robben Island“". https://en.unesco.org/courier/2018-3/ unesco-courier-70-only-journal-nelson-mandela-read-robben-island.

Darnton, Robert. 1982. »What is the History of Books. « Daedalus 111: 3 65-83.

Darnton, Robert. 2007. »What is the History of Books? Revisited . Modern Intellectual History 4/3 495-508.

Dausse, Aurélia. 2018. Remembering Sandy Koffler, my grandfather . https:// en.unesco.org/courier/2018-4/remembering-sandy-koffler-my-grandfather (besøgt 20/3 2019)

Defourny, Vincent. 2003. »Public Information in the UNESCO: Toward a Strategic Role. «I The Global Public Relations Handbook: Theory, Research, and Practice , af Krishnamurthy Sriramesh \& Dejan Vercic. Routledge .

Droit, Roger-Pol. 2005. Humanity in the making. Overview of the Intellectual Historiy of UNESCO 1945-2005. Paris: Unesco.

Duedahl, Poul. 2016. A History of UNESCO. Redigeret af Poul Duedahl. Houndmills: Palgrave MacMillan.

—. 2017. Fra overmenneske til UNESCO-menneske. Racebegrebet i Danmark 1890-1965. Odense: Syddansk Universitetsforlag.

Duedahl, Poul. 2015. »Fra race til etnicitet. UNESCO og den mentale ingeniørkunst i Danmark 1945-65. « TEMP - tidsskrift for historie 5.

Lässig, Simone. 2016. »The History of Knowledge and the Expansion of the Historical Research Agenda. « Bulletin of the GHI, Washington 29-44.

Lind, Lars. 1950. »UNESCO's work in mass communications. « The Library Quarterly: Information, Community, Policy, 20/4 259-271 .

Marchand, Suzanne. 2019. »How Much Knowledge is Woth Knowing? An Amercian Intellectual Historian's Thoughts on the Geschichte des Wissens. « Ber. Wissenschaftsgesch. 42 126-149.

Markarian, Roberto $2018 »$ The UNESCO Courier is 70: Attending the school of free thought . "UNESCO. Senest hentet eller vist den 1. Marts 2019. https:// en.unesco.org/courier/2018-2/unesco-courier-70-attending-school-freethought.

Nuotio, Lotta. 2006. »Spreading the news: The natural sciences in the UNESCO Courier, 1947-1965. «I Sixty Years of Science at Unesco 1945-2005. Paris: Unesco. 
Pol-Droit, Roger. 2005. Humanity in the making. Overview of the Intellectual Historiy of UNESCO 1945-2005. Paris: UNESCO.

Sarasin, Philipp \& Andreas Kilcher. 2011. »Editorial 7 .« Nach Feierabend: Zürcher Jahrbuch für Wissensgeschichte 7.

Secord, James. 2004. »Knowledge in Transit'. "Isis 95/4.

Simonsen, Maria \& Laura Skouvig. 2019. »Videnshistorie Nye veje i historievidenskaberne'. «TEMP- Tidsskrift for historie 20-21.

Simonsen, Maria. 2007. »Én vej. En historisk analyse af UNESCOs standardsættende instrumenter og den danske UNESCONationalkommissions diskurs på det kvindepolitiske område. « (Aalborg Universitet) 27-35.

Valderrama, Fernando. 1995. A History of UNESCO. Paris: UNESCO.

Östling, Johan \& David Larsson Heidenblad. 2017. »Cirkulation - ett kunskapshistoriskt nyckelbegrepp.« Historisk Tidskrift 137:2 269-284 .

Östling, Johan, David Larsson Heidenblad, Erling Sandmo, Anna Nilsson Hammer \& Kari H. Nordberg. 2018. Circulation of knowledge.Explorations in the History of Knowledge. Lund: Nordic Academic Press.

\section{Summary}

\section{A window on the world}

\section{From constitution to journal: a study of the transformation and circulation of knowledge in the UNESCO Courier}

UNESCO was one of the most influential knowledge-producing organizations in the post-war period. Through the four cardinal points: education, science, culture and communication, the intergovernmental organization pursued the peacebuilding work after World War II by adopting a large number of official documents in the forms of constitutions, resolutions and recommendations that were intended to guide the member states in how to implement UNESCO's ideas and ideals. Working on a political level was only one part in UNESCO's mission; the cornerstone of the organization's extensive attempts to promote peace and democratic values was its ability to communicate its mission with the world outside of the headquarters/the political circles. One of the first steps in reaching a wider audience was the publication of the popular magazine UNESCO Courier that was intended to be the public voice of UNESCO. What happens to UNESCO's ideas and ideals when they are in motion? How is the knowledge that UNESCO wishes to disseminate, expressed when it appears in new forms and media? 